\title{
Ukraine's foreign trade: responses to global challenges
}

\author{
Svitlana Radzivivska ${ }^{1, *}$ and Ivan $\mathrm{Us}^{2, * *}$ \\ ${ }^{1}$ National Academy of Management, 15 Ushynskoho Str., Kyiv, 03151, Ukraine \\ ${ }^{2}$ The National Institute for Strategic Studies, 7-a Pyrogova Str., Kyiv, 01030, Ukraine
}

\begin{abstract}
The overview of the country's trade with all the continents during the period of 2000-2019 is given. The description of the commodity structure of exports/imports of goods, with particular attention to the industrial products, is followed by the detailed analysis of Ukraine's foreign trade in 2020. The decrease in Ukraine's foreign trade in 2020 by $6.4 \%$ is fully consistent with the projected WTO reduction of world trade in 2020 by 9.2\%. Although COVID-19 had negative impact on Ukraine's trade with the EU and the EAEU, it contributed to closer trade ties with Asia, improving Ukraine's trade balance. The government and the national business elite should aim at solving the problems of increasing the volume and improving the commodity structure of Ukraine's foreign trade with emphasis on the development of transport system for exporting agricultural and food products to the developed countries of the West and to the prospective economies of the East and the South. It is essential, on the one hand, to focus on the inflows of FDI and their appropriate use, and, on the other hand, on Ukraine's participation in the formation of GVCs, global production networks. In the conditions of the Fourth industrial revolution, the economy finds itself transformed due to the fundamental changes. The optimization of foreign trade relations of Ukraine will not only improve the economy, but also enable the country to become a better functioning element of the global economic system.
\end{abstract}

\section{Introduction}

The globalization of the world economy intensifies the processes of international division of labor, causing transformations in the directions and intensity of trade flows between countries. The severe competition for resources, the need to preserve the environment, and the Fourth Industrial Revolution, as well as the global challenges, e.g. the Crisis of 2008-2009, sanctions policy, COVID-19 [1, 2], require the states to adapt their production and, consequently, foreign economic activities to meet the new requirements, created by the specific development of the global processes [3]. Timely understanding of the new requirements and making appropriate decisions are the imperatives for any country to survive and function in the global economic system.

The conclusions of the classical, neo-classical, as well as modern international trade theories are gaining new insights nowadays since foreign trade is the key factor influencing economic growth not only of separate states, but regional blocks (e.g., USMCA, EU, ASEAN, EAEU, etc.), transcontinental coalitions (e.g., Transatlantic Trade and Investment Partnership, Regional Comprehensive Economic Partnership, etc.), as well as the global economy as a whole [4-7].

That is why, in our opinion, the optimization of foreign trade relations of Ukraine is of vital importance since it will not only improve the country's economy, but also

\footnotetext{
*e-mail: svitrad98@ukr.net

**e-mail: ivanusus@gmail.com
}

enable Ukraine to become a better functioning element of the global economic system [8]. Our hope is that Ukraine will be able to adapt to the new realities and become a more confident and sufficient player of the modern world economy - an open complex stochastic nonlinear system, the elements of which are highly interconnected and interdependent [9-20].

The methodological basis of the research is the systemic approach combined with the historical and logical methods, as well as the method of comparative statistics analysis, based on the data provided by the State Statistics Service of Ukraine and the State Customs Service of Ukraine.

The paper comprehensively examines three interrelated aspects of Ukraine's foreign trade: 1) the geographical expansion, i.e. its globalization; 2) the development of its commodity structure, i.e. its specialization; 3) the impact of COVID-19 on it.

Ukraine's economy is shrinking, but more developed countries have it worse. The country's biggest stroke of luck is that industries that suffered most from COVID-19 - tourism, petroleum production, services, and manufacturing - don't dominate the economy [21]. Ukraine's main sectors like agriculture (40\% of export) and metallurgy either escaped unscathed or even grew [22]. COVID-19 contributed to solving the topical problem of the large trade deficit of Ukraine [23] since in 2020 the negative balance of trade is more than twice less than in 2019. At the same time COVID-19 has had negative impact on Ukraine's eco- 
nomic relations with both - the EU and the EAEU - and positive impact on those with the Asian economies.

The objective of the paper is to demonstrate the peculiarities of Ukraine's adaptation to global challenges by providing the detailed analysis of Ukraine's merchandise trade with the purpose of improving the country's foreign economic activity.

\section{Overview of Ukraine's intensity of trade flows of goods with continents in the 21st century}

Over the past 20 years Ukraine has made some progress in terms of expanding the geography of its trade. Since one of the key peculiarities of the economy is that the share of trade in goods in all trade in goods and services makes up for more than $80 \%$ [23], we will focus on the analysis of exports and imports of goods.

The official site of the State Statistics Service provides data for the analysis of the dynamics of geographical structure of Ukraine's exports of goods (table 1) and imports of goods (table 2). The dynamics of Ukraine's exports/imports of goods is calculated as the change in the ratio of volume of goods taken at the particular year 2005, 2010, 2015, 2019 to 2000 since the benchmark year adopted for our analysis is 2000 . For example, table 1 indicates that Ukraine's exports of goods to Europe in 2005 increased 2.32 times compared to 2000 , in $2010-2.95$, in $2015-2.83$, and in $2019-5.71$ times. In 2019 the share of exports of the Ukrainian goods to Europe was 53.6\% of total merchandise exports of Ukraine. Thus, the European countries are the main consumers of the Ukrainian products.

The exports of Ukraine's goods to Asia are characterized by the following dynamics: in 2005 they grew 2.47 times compared to 2000 , in $2010-3.95$, in $2015-3.56$, in 2019 - 4.79 times (table 1). In 2019 the share of Ukraine's exports of goods to the Asian countries reached $33.37 \%$ of all the Ukrainian merchandise exports. Moreover, in 2010 the share of Ukraine's exports of products to Europe and Asia was nearly the same $-42 \%$ of the Ukrainian goods to each continent, but in 2019 Europe took the leading role with nearly $56 \%$ while Asia received $33 \%$ of Ukraine's commodities. Still, the analysis of table 1 allows to conclude that the Asian countries are important partners for Ukraine.

It is interesting to note that Ukraine's exports of products to the African countries in 2005 increased 3.27 times compared to 2000 , in $2010-4.13$, in 2015 - 5.2 times while the country's exports of goods to the American countries in 2005 rose 1.5 times compared to 2000, in 2010 - 1.64, 2015 - 0.65 times. In 2005 Ukraine's merchandise exports to Australia and Oceania grew 1.96 times compared to 2000 , in $2010-4.06$ times. Considering Ukraine's trade with Africa, it is obvious that Ukraine's potential is to be fulfilled yet. At the same time trade relations of Ukraine with the American countries demonstrate that their role as consumers of the Ukrainian goods is declining. To sum up, Europe and Asia consumed $86.97 \%$ of Ukrainian goods in 2019, Africa $-9.97 \%$.
Table 1. Dynamics of geographical structure of Ukraine's exports of goods, 2000-2019, based on [24]

\begin{tabular}{|c|c|c|c|c|c|c|}
\hline \multirow[b]{2}{*}{2000} & \multicolumn{2}{|c|}{$\begin{array}{c}\text { Total, } \\
\text { including the } \\
\text { undistributed } \\
\text { goods }\end{array}$} & CIS & $\begin{array}{l}\text { countries } \\
\text { of the } \\
\text { world }\end{array}$ & $\begin{array}{l}\text { ler } \\
\text { tries } \\
\text { he } \\
\text { rld }\end{array}$ & $\mathbf{E U}$ \\
\hline & & 4572.5 & 4459.7 & 101 & 12.8 & 576.3 \\
\hline 2005 & & 4228.4 & 10531.1 & 236 & $97.3 \quad 10$ & 293.3 \\
\hline 2010 & & 1405.2 & 18740.6 & 326 & $64.6 \quad 13$ & 085.3 \\
\hline 2015 & & 8127.1 & 7806.1 & 303 & $21.0 \quad 13$ & 015.2 \\
\hline 2019 & & 0054.6 & - & & $-20^{\circ}$ & 750.7 \\
\hline \multirow{4}{*}{$\begin{array}{c}2015 \\
/ 2000, \\
\% \\
\end{array}$} & & & & & & \\
\hline & & 261.6 & 175.0 & & 99.8 & 284.4 \\
\hline & \multicolumn{2}{|c|}{ TOTAL } & \multicolumn{2}{|c|}{ EUROPE } & \multicolumn{2}{|c|}{ ASIA } \\
\hline & $\begin{array}{c}\text { mln } \\
\text { USD }\end{array}$ & $\%$ & $\begin{array}{c}\text { mln } \\
\text { USD }\end{array}$ & $\%$ & $\begin{array}{c}\text { mln } \\
\text { USD }\end{array}$ & $\%$ \\
\hline 2000 & 10111.9 & 100 & 4680.2 & 46.28 & 3475.7 & $\mathbf{3 4 . 3 7}$ \\
\hline 2005 & 23696.2 & 100 & 10881.4 & 45.92 & 8576.0 & 36.19 \\
\hline 2010 & 32592.1 & 100 & 13829.6 & 42.43 & 13715.4 & 42.08 \\
\hline 2015 & 30229.7 & 100 & 13248.3 & 43.83 & 12378.9 & 40.95 \\
\hline 2019 & 49884.0 & 100 & 26739.5 & 53.60 & 16646.1 & 33.37 \\
\hline \multicolumn{7}{|l|}{ 2015/ } \\
\hline $\begin{array}{c}2000, \\
\%\end{array}$ & \multicolumn{2}{|l|}{299.0} & \multicolumn{2}{|l|}{283.1} & \multicolumn{2}{|l|}{356.2} \\
\hline 2019/ & \multirow{2}{*}{\multicolumn{2}{|c|}{493.3}} & \multirow{2}{*}{\multicolumn{2}{|c|}{571.3}} & \multirow{2}{*}{\multicolumn{2}{|c|}{478,9}} \\
\hline $\begin{array}{c}2000, \\
\%\end{array}$ & & & & & & \\
\hline & \multicolumn{2}{|c|}{ AFRICA } & \multicolumn{2}{|c|}{ AMERICA } & \multicolumn{2}{|c|}{$\begin{array}{c}\text { AUSTRALIA } \\
\text { and } \\
\text { OCEANIA }\end{array}$} \\
\hline & $\begin{array}{l}\text { mln } \\
\text { USD }\end{array}$ & $\%$ & $\begin{array}{c}\mathrm{mln} \\
\text { USD }\end{array}$ & $\%$ & $\begin{array}{c}\mathrm{mln} \\
\text { USD }\end{array}$ & $\%$ \\
\hline 2000 & 731.5 & 7.23 & 1217.5 & 12.04 & 7.0 & $\overline{0.08}$ \\
\hline 2005 & 2393.9 & 10.10 & 1831.2 & 7.73 & 13.7 & 0.06 \\
\hline 2010 & 3018.7 & 9.26 & 2000.0 & 6.14 & 28.4 & 0.09 \\
\hline 2015 & 3803.3 & 12.58 & 785.6 & 2.60 & 13.6 & 0.04 \\
\hline 2019 & 4971.5 & 9.97 & 1467.9 & 2.94 & 59.0 & 0.12 \\
\hline \multicolumn{7}{|l|}{ 2015/ } \\
\hline $\begin{array}{c}2000 \\
\%\end{array}$ & 519.9 & & 64.5 & & 194.3 & \\
\hline 2019/ & & & & & & \\
\hline $\begin{array}{c}2000 \\
\%\end{array}$ & 679.6 & & 120.6 & & 842.9 & \\
\hline
\end{tabular}

Let's have a closer look at the dynamics of geographical structure of Ukraine's imports of goods, presented in table 2. The analysis of Ukraine's imports of products from Europe indicates that the country's imports from the European states in 2005 increased 2.94 times compared to 2000 , in 2010 - 4.64 times, in 2015 - 3.87 times, in 2019 8.81 times. Merchandise imports from Asia to Ukraine in 2005 grew 5.56 times compared to 2000, in $2010-11.9$, in $2015-8.59$, in $2019-20.65$ times.

As table 2 shows, the share of imports commodities from Europe to Ukraine in 2000 was $72.75 \%$ while in 2019 it was $62.58 \%$ of total merchandise imports of Ukraine. 
Table 2. Dynamics of geographical structure of Ukraine's imports of goods, 2000-2019, based on [24]

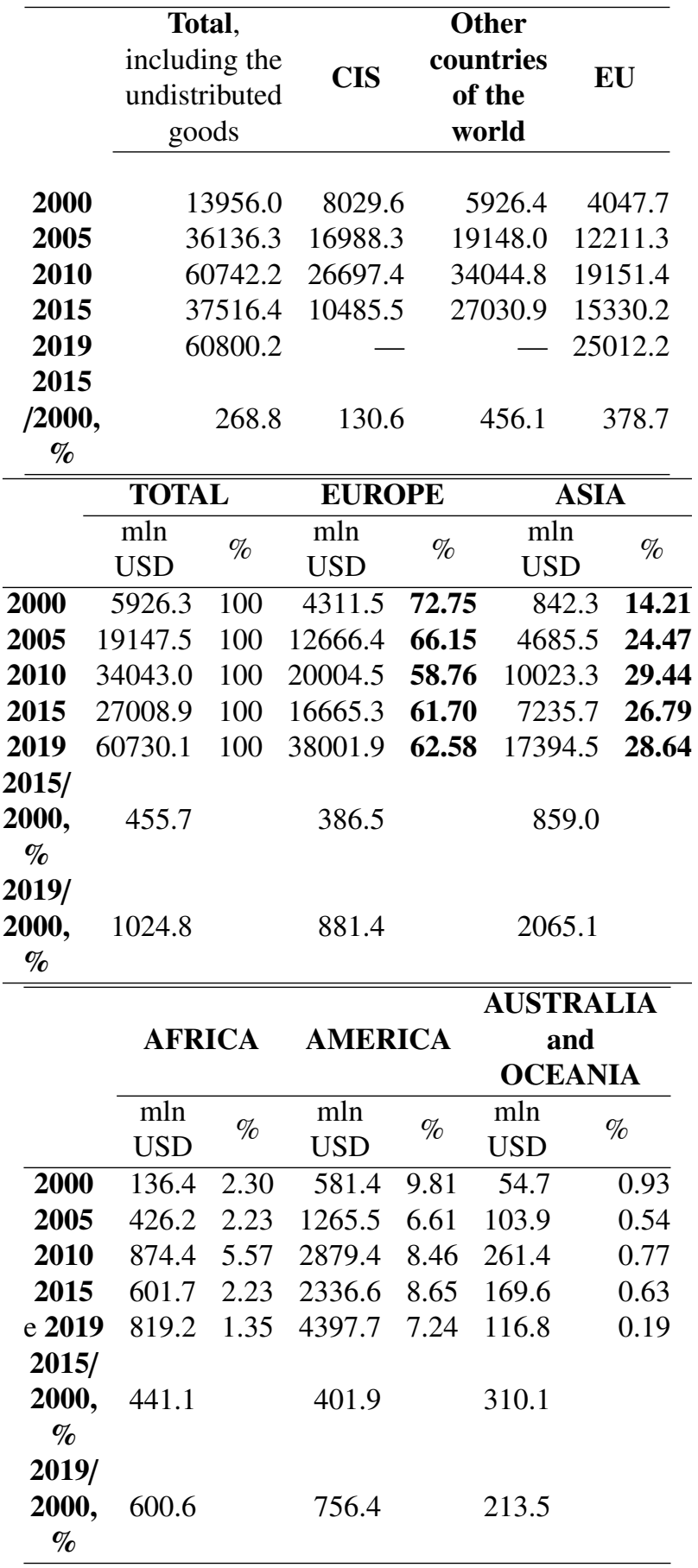

At the same time, the share of imports of goods from the Asian countries to Ukraine in 2000 was $14.21 \%$, and in 2019 reached $28.64 \%$ of total imports of products. Thus, the analysis of trade relations of Ukraine with the Asian countries suggests that their role as suppliers of goods for Ukraine is becoming more important. However, it should be noted that Ukraine has been having negative balance of trade in goods with Europe since 2005 (-1785 mln USD), which has grown to - $11262.4 \mathrm{mln}$ USD in 2019, while the trade balance of Ukraine with Asia had been positive throughout the analyzed period up until 2019 when it became negative(-748.4 mln USD). So, up until 2019
Ukraine's trade in goods with both - Europe and Asia didn't contribute to solving the problem of decreasing the large trade deficit of the country [23].

Imports of products from America to Ukraine in 2005 increased 2.18 times, in 2010 - 5 times, in 2015 - 4 times, in $2019-7.56$ times. The share of imports from the American countries in 2019 was $7.24 \%$ of total imports of goods of Ukraine. Nevertheless, goods imports from Africa to Ukraine in 2005 rose 3.12 times, in $2010-6.41$ times, in $2015-4.41$, in $2019-6$ times.

It should be underlined that the trade balance of goods of Ukraine with the African countries is positive, while with those of America - negative. Merchandise imports from Australia and Oceania to Ukraine in 2005 grew 1.9 times compared to 2000 , in $2010-4.8$, in 2015 - 3.1, in 2019 - 2.1 times. Ukraine's trade with Africa and especially Australia and Oceania has not been developed - the turnover of goods between Ukraine and those continents is not significant. To sum up, the European countries remain the main suppliers of goods for Ukraine; however, the Asian ones steadily improve their positions.

\section{Ukraine's trade specialization and its deindustrialization}

Let's have a closer look at the commodity structure of exports during the period of 2016-2019 (table 3).

As table 3 shows, the exports of Ukraine are formed by the following main product groups: I. Live animals and livestock products; II. Plant products; III. Animal or plant fats and oils; IV. Finished food industry products; V. Mineral products; VI. Products of chemical and allied industries; XV. Base metals and preparations thereof; XVI. Machines, equipment and mechanisms, electric and technical equipment; XVII. Ground, air and water transport facilities. The linear regression trend model of the relationship between the two variables - the time and the size of goods is calculated by the method of least squares. The results presented in the tables 3 and 4 are based on the Microsoft Excel program. The pair linear regression is applied in the research. The models enable the economic interpretation and the analysis of the current economic situation, as well as the suggestions on the ways for its improvement.

During the period under review, the share of "I. Live animals and livestock products" grew from $2.13 \%$ to $2.55 \%$ of Ukraine's merchandise exports (table 3 ). There was also an increase in the share of "II. Plant products" from $22.26 \%$ to $25.8 \%$. However, the share of merchandise exports of "III. Animal or plant fats and oils" decreased from $10.9 \%$ to $9.45 \%$ and "IV. Finished food industry products" - from $6.74 \%$ to $6.43 \%$.

Thus, in 2019 the share of food and agricultural products was $44.23 \%$ of all exports of goods of Ukraine. Moreover, as table 3 indicates "V. Mineral products", "VI. Products of chemical and allied industries"; "XV. Base metals and preparations thereof" accounted for $34.07 \%$ of all merchandise exports in 2019.

It should be emphasized that all the above described product groups (I, II, III, IV, as well as V, VI, XV) are 
Table 3. Dynamics of commodity structure of volume (mln USD) and share (\%) of Ukraine's exports of goods, 2016-2019, based on [24]

\begin{tabular}{|c|c|c|c|c|}
\hline MAIN COMMODITY GROUPS & 2016 & 2017 & 2018 & 2019 \\
\hline \multirow{2}{*}{ I. Live animals and livestock products } & 775.0 & 1108.8 & 1210.6 & 1277.0 \\
\hline & 2.13 & 2.56 & 2.55 & 2.55 \\
\hline Volume trend & \multicolumn{4}{|c|}{$y=160.78 x+690.9$} \\
\hline \multirow{2}{*}{ II. Plant products } & 8093.7 & 9215.7 & 9886.1 & 12914.5 \\
\hline & 22.26 & 21.3 & 20.89 & 25.8 \\
\hline Volume trend & \multicolumn{4}{|c|}{$y=1513.3 x+6244.3$} \\
\hline \multirow{2}{*}{ III. Animal or plant fats and oils } & 3963.0 & 4605.7 & 4496.5 & 4732.2 \\
\hline & 10.9 & 10.65 & 9.5 & 9.45 \\
\hline Volume trend & \multicolumn{4}{|c|}{$y=219.84 x+3899.8$} \\
\hline \multirow{2}{*}{ IV. Finished food industry products } & 2450.1 & 2826.7 & 3018.6 & 3220.4 \\
\hline & 6.74 & 6.53 & 6.38 & 6.43 \\
\hline Volume trend & \multicolumn{4}{|c|}{$y=250.28 x+2253.3$} \\
\hline \multirow{2}{*}{ V. Mineral products } & 2728.8 & 3947.7 & 4339.6 & 4866.5 \\
\hline & 7.5 & 9.12 & 9.16 & 9.72 \\
\hline Volume trend & \multicolumn{4}{|c|}{$y=680.5 x+2269.4$} \\
\hline \multirow{2}{*}{ VI. Products of chemical and allied industries } & 1558.2 & 1660.6 & 1871.3 & 1930.8 \\
\hline & 4.29 & 3.84 & 3.95 & 3.86 \\
\hline Volume trend & \multicolumn{4}{|c|}{$y=132.85 x+1423.1$} \\
\hline \multirow{2}{*}{ XV. Base metals and preparations thereof } & 8338.9 & 10124.6 & 11632.7 & 10255.7 \\
\hline & 22.93 & 23.4 & 24.58 & 20.49 \\
\hline Volume trend & \multicolumn{4}{|c|}{$y=725.85 x+8273.4$} \\
\hline \multirow{3}{*}{$\begin{array}{l}\text { XVI. Machines, equipment and mechanisms, } \\
\text { electric and technical equipment } \\
\text { Volume trend }\end{array}$} & 3637.9 & 4276.8 & 4654.7 & 4464.4 \\
\hline & 10.0 & 9.89 & 9.83 & 8.92 \\
\hline & \multicolumn{4}{|c|}{$y=285.74 x+3544.1$} \\
\hline \multirow{2}{*}{ XVII. Ground, air and water transport facilities } & 555.7 & 625.9 & 669.3 & 882.3 \\
\hline & 1.53 & 1.45 & 1.41 & 1.76 \\
\hline Volume trend & \multicolumn{4}{|c|}{$y=102.32 x+427.5$} \\
\hline TOTAL EXPORTS & $\begin{array}{l}36361 . \\
100\end{array}$ & $\begin{array}{l}43264.7 \\
100\end{array}$ & $\begin{array}{l}47335.0 \\
100\end{array}$ & $\begin{array}{l}50054.6 \\
100\end{array}$ \\
\hline
\end{tabular}

considered to be low value-added and their total share in 2019 was $78.3 \%$ of all Ukraine's goods for exports.

The analysis of the Ukrainian exports and imports of the selected industrial goods - "XVI. Machines, equipment and mechanisms, electric and technical equipment" and "XVII. Ground, air and water transport facilities" demonstrates that in exports of Ukraine the share of those groups of goods in all the exports of goods is decreasing (in $2016-11.53 \%$, in $2019-10.68 \%$ ) while the share of those groups of goods in all the imports of goods is increasing (in 2016-27.64\%, in 2019-32.04\%).

As the analysis of tables 3 and 4 suggests, Ukraine is in a state of economic decline and deindustrialization. According to Viktor Halasiuk, the country has to use the available resources to become a world leader in certain niches. So, it is necessary to develop the sectors Ukraine can quickly scale by several times [25]. In this regard, we believe that the first and foremost factor of catchingup development is the state itself interested in improving competitiveness of its economy in the global market.

Thus, the reindustrialization should be reviewed with the objective of identifying the nature of commodity imports of Ukraine and manifest itself in the increase in its commodity exports of industrial goods. Finally, Ukraine's quick and careless participation in globalization, orga- nized according to the recommendations of the Washington Consensus, has brought negative results, i.e. the large trade deficit, the drastic decline of its high tech production, orientation of the country's economy development primarily on agricultural and food production, on the extraction of raw materials, their primary processing. Consequently, the great number of highly skilled professionals could not find job corresponding to their qualifications, and the majority of them was forced either to work in trade or to emigrate abroad. Overcoming negative tendencies in the economy of Ukraine requires the refusal of the recommendations of the Washington Consensus, above all of the neoliberalism ideology, forming their basis and contradicting the main postulate of adhering to justice in the world.

G. Gereffi noted that the Washington Consensus model of development, which held away from the mid-1980s through the mid-2000s, is a nation-state-centered view of the global economy, in which countries are the primary units of analysis in international production and trade. Then, the scholar emphasized that "the GVC framework fundamentally challenges this view of the global economy and it provides a different interpretation of the key drivers of change over the past four decades [26]. GVCs account for around half of world trade today. On the one hand, GVC participation is determined by factor endowments, 
Table 4. Dynamics of commodity structure of volume (mln USD) and share (\%) of Ukraine's imports of goods, 2016-2019, based on [24]

\begin{tabular}{|c|c|c|c|c|}
\hline MAIN COMMODITY GROUPS & 2016 & 2017 & 2018 & 2019 \\
\hline \multirow{2}{*}{ I. Live animals and livestock products } & 626.3 & 731.5 & 918.0 & 1071.5 \\
\hline & 1.6 & 1.47 & 1.61 & 1.76 \\
\hline Volume trend & \multicolumn{4}{|c|}{$y=152.21 x+456.3$} \\
\hline \multirow{2}{*}{ II. Plant products } & 1284.8 & 1368.0 & 1529.2 & 1794.6 \\
\hline & 3.27 & 2.76 & 2.67 & 2.95 \\
\hline Volume trend & \multicolumn{4}{|c|}{$y=169.06 x+1071.5$} \\
\hline \multirow{2}{*}{ III. Animal or plant fats and oils } & 246.0 & 266.6 & 267.4 & 253.3 \\
\hline & 0.63 & 0.54 & 0.47 & 0.42 \\
\hline Volume trend & \multicolumn{4}{|c|}{$y=2.27 x+252.65$} \\
\hline \multirow{2}{*}{ IV. Finished food industry products } & 1734.0 & 1935.0 & 2340.9 & 2616.6 \\
\hline & 4.42 & 3.9 & 4.09 & 4.3 \\
\hline Volume trend & \multicolumn{4}{|c|}{$y=305.37 x+1393.2$} \\
\hline \multirow{2}{*}{ V. Mineral products } & 8495.0 & 12504.7 & 14191.9 & 12984.6 \\
\hline & 21.64 & 25.21 & 24.82 & 21.36 \\
\hline Volume trend & \multicolumn{4}{|c|}{$y=1515.6 x+8255.1$} \\
\hline \multirow{2}{*}{ VI. Products of chemical and allied industries } & 5619.5 & 6545.9 & 7058.3 & 7483.4 \\
\hline & 14.32 & 13.2 & 12.34 & 12.3 \\
\hline Volume trend & \multicolumn{4}{|c|}{$y=610.41 x+5150.8$} \\
\hline \multirow{2}{*}{ XV. Base metals and preparations thereof } & 2306.5 & 3012.8 & 3575.2 & 3650.7 \\
\hline & 5.88 & 6.07 & 6.25 & 6.0 \\
\hline Volume trend & \multicolumn{4}{|c|}{$y=459.5 x+1987.6$} \\
\hline \multirow{3}{*}{$\begin{array}{l}\text { XVI. Machines, equipment and mechanisms, } \\
\text { electric and technical equipment } \\
\text { Volume trend }\end{array}$} & 7889.4 & 9902.6 & 11955.2 & 13312.8 \\
\hline & 20.1 & 19.96 & 20.91 & 21.9 \\
\hline & \multicolumn{4}{|c|}{$y=1832.3 x+6184.3$} \\
\hline \multirow{2}{*}{ XVII. Ground, air and water transport facilities } & 2959.5 & 4182.1 & 4554.0 & 6162.8 \\
\hline & 7.54 & 8.43 & 7.96 & 10.14 \\
\hline Volume trend & \multicolumn{4}{|c|}{$y=998.18 x+1969.2$} \\
\hline TOTAL EXPORTS & $\begin{array}{l}39249 . \\
100\end{array}$ & $\begin{array}{l}49607.2 \\
100\end{array}$ & $\begin{array}{l}57187.6 \\
100\end{array}$ & $\begin{array}{l}60800.2 \\
100\end{array}$ \\
\hline
\end{tabular}

geography, market size, and institution; on the other hand, these fundamentals alone need not dictate destiny since policies to attract FDI can remedy the scarcity of capital, technology, and management skills [27]. In our opinion, the development of industry requires the expansion of demand for products, the improvement of the rules to access the markets, the diversification of the geographical directions and commodity structure of the industrial exports.

In order to solve the problems of increasing the volume and improving the commodity structure of Ukraine's foreign trade, firstly, it is essential to focus on the inflows of FDI and their appropriate use, and, secondly, on the active involvement in global value chains and production networks on regional and global levels. These actions will promote the formation of the socio-market economy in Ukraine, the knowledge economy, approval of justice and high technology, the economy which enables to keep the environment in the parameters required for the functioning of the ecosystem and for preventing climatic disasters on regional and global levels.

\section{World trade in 2020}

World trade in 2020 marked a significant decline as the result of countries' measures to combat the spread of
COVID-19. The most significant reduction occurred in the second quarter of 2020, when compared to the second quarter of 2019, the value of world trade decreased by $21 \%$ [28]. For comparison, the decline in the value of trade in goods during the financial crisis was deeper (in the second quarter of 2009 there was a decline of 33\%).

In terms of monthly indicators, the value of world trade in goods decreased by $23 \%$ in April 2020 compared to April 2019 and by $26 \%$ in May (monthly estimates are based on data from 72 countries, which accounted for $92 \%$ of world trade in goods). In the third quarter of 2020, the volume of trade in goods increased by $11.6 \%$ compared to the previous quarter. Despite this growth, the value of trade in July-September was $5.6 \%$ lower than in the same period of 2019. This improvement has taken place largely as the European countries began to ease restrictive measures. At the same time some of the Asian states saw a slight increase, reflecting different pandemic trajectories in different regions.

The actual dynamics has led the World Trade Organization to revise its own forecast of the world trade in 2020 for the better. If in April 2020, according to the optimistic scenario, a reduction of $12.9 \%$ was forecast, and according to the pessimistic scenario by $31.9 \%$, in the October forecast the WTO estimates a decrease in world trade in 
goods at $9.2 \%$ [29]. Thus, the updated forecast is better than the optimistic scenario, which is evidence for better adaptation of the world trade processes in the conditions of pandemic caused by the COVID-19 than it was expected in April.

According to WTO forecasts, Asian countries will come out of the crisis faster than countries in the other regions. At the end of 2020, their exports are projected to decline by $4.5 \%$ and imports by $4.4 \%$, while European exports will decline by $11.7 \%$ and North American countries by $14.7 \%$. Imports from European countries will decrease by $10.3 \%$ and from North America by $8.7 \%$. It should be noted that the WTO made its forecast before the data for the three quarters of 2020 were obtained, according to which the volume of world trade in goods was lower by $8.2 \%$ comparing with the same period of 2019 . The sooner the effects of the COVID-19 can be overcome, the greater will be the resumption of world trade and the return of the world to the track of globalization, which in the context of shifting the emphasis from globalization to regionalization is important [30].

\section{Foreign trade in goods of Ukraine in 2020}

Following the results of 2020, the value of foreign trade in goods of Ukraine decreased by $6.4 \%$ compared to the same period of 2019 [31]. The decline was mainly due to reduction in imports of goods by $10.3 \%$, while their exports decreased by $1.7 \%$. Thus, shrinking Ukraine's foreign trade is in a better state in comparison with the WTO's projected reduction for the world trade in 2020.

As in the rest of the world, the main reduction during 2020 occurred in April and May, when the turnover decreased compared to the corresponding months of 2019 by $17.4 \%$ and $27.3 \%$, while for the period from January to March the reduction was $1 \%$, and for the period from June to December, turnover dropped by $4 \%$ (figure 1). Significantly, the reduction in the value of trade was due to lower prices, as the physical volume of foreign trade in $2020 \mathrm{de}$ creased by $4.7 \%$.

Turnover in April 2020 was 1.6 bln USD less than in March and amounted to 7.3 bln USD. It was even lower in May -6.9 bln USD. In the second half of 2020 it began to show steady growth. In June it rose to 7.4 bln USD, in July - to 8.3 bln USD, in August - to 8.7 bln USD, in September - to 8.9 bln USD, in October - to 9.6 bln USD, in November - to 10.1 bln USD and in December - to 10.7 bln USD (figure 2). Higher rates of decline in imports of goods in comparison with exports of goods resulted in more than two times reduction of the negative balance in foreign trade. If the negative balance for 2019 was 10.4 bln USD, then in 2020 it decreased to 5 bln USD. Exports of goods for 2020 compared to 2019 dropped by 0.8 bln USD and amounted to 49.2 bln USD.

Moreover, during the fall of 2020, we observed the tendency of exports growth compared to the fall of 2019. In September the exports increased by $2.8 \%$, in October - by $1.4 \%$ and in November - by $9.1 \%$. In December, export growth was more significant and amounted to $18.5 \%$ (figure 1) - the fact demonstrates the gradual resumption of economic activity in the main markets for domestic products.

It should be noted that the reduction in 2020 was formed by lower revenues from exports of metals and metal products; goods of this group decreased by $1.2 \mathrm{bln}$ USD, which was $11.7 \%$ lower than at the same period last year. At the same time exports of fuel and energy products dropped (by $307 \mathrm{mln}$ USD or $35.6 \%$ ), as well as machinery, equipment and transport (by $98 \mathrm{mln}$ USD or $1.8 \%$ ). However, exports of mineral products increased by 772 mln USD, or $19.3 \%$. Exports of food products and agricultural products also increased by $49 \mathrm{mln}$ USD or $0.2 \%$. Despite a slight increase, the share of this sector in the commodity structure of exports increased more significantly. If in 2019 the share of food products and agricultural products in the commodity structure was $44.3 \%$, in 2020 it increased to $45.1 \%$. At the same time during this period the share of metals and metal products decreased from $20.5 \%$ to $18.4 \%$. These two product groups account for almost two thirds of total exports of goods from Ukraine (table 5).

Table 5. Commodity structure of Ukraine's foreign trade in 2020, bln USD

\begin{tabular}{lll}
\hline Industry & Export & Import \\
\hline Food and agricultural products & 22,2 & 6,5 \\
Mineral products & 4,8 & 0,6 \\
Fuel and energy products & 0,6 & 8,0 \\
Chemical industry products, rubber & 2,7 & 10,8 \\
Textiles, footwear & 0,9 & 2,7 \\
Metals and articles thereof & 9,1 & 3,2 \\
Machinery, equipment and transport & 5,4 & 18,6 \\
Other goods & 3,5 & 3,8 \\
\hline
\end{tabular}

The analysis indicates that the level of reduction in the value of exports was similar to the level of reduction in its physical volumes (decreased by $1.5 \%$ ). This is largely due to the fluctuations in prices for main product groups of Ukraine's exports. It's worth to underline that price trends had different directions.

If prices for the agricultural exports increased (as a result, when the value of exports of goods of this group increased by $0.2 \%$, their physical volumes decreased by $9 \%$ ), while prices for the other goods mostly fell. It is due to the decline in prices for chemical products that the increase in the physical volume of their exports by $24.9 \%$ in value brought much lower growth (by 2.3\%).

Although the decline in world metal prices resulted in the reduction of the value of exports of this product group by $14.5 \%$, their physical volumes remained at the level of the previous year. Prices for machine-building products were more stable. With the decrease in the physical volume of exports of goods in this group by $5,8 \%$, value receipts from them fell by $1.8 \%$.

Imports of goods in 2020 compared to 2019 decreased by 6.2 bln USD to 54.2 bln USD. The decline in imports was largely due to reduction in Ukraine's spending on fuel 


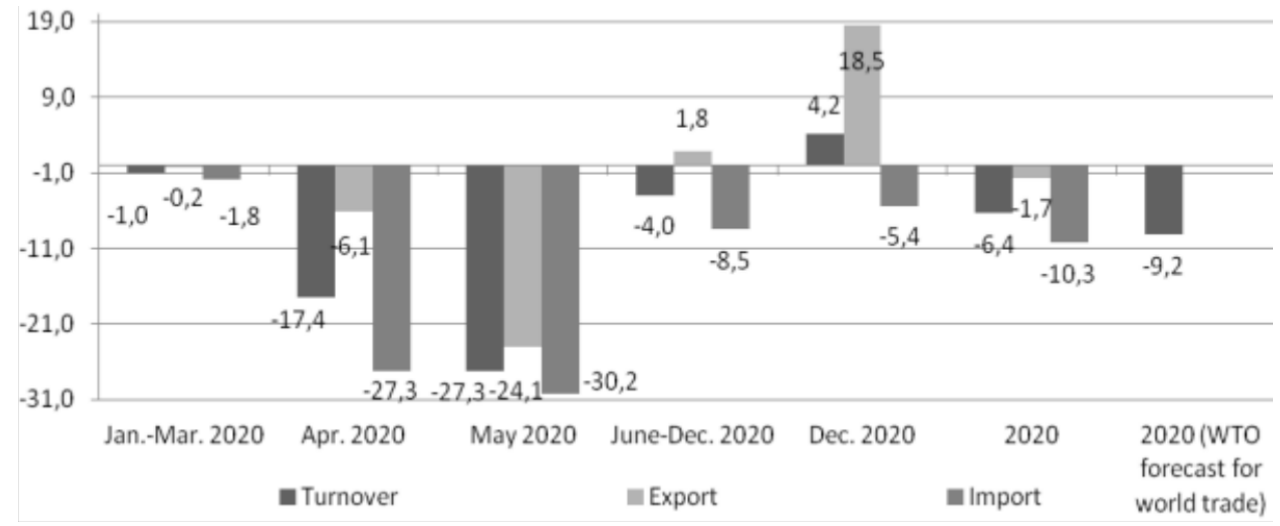

Figure 1. Dynamics of commodity foreign trade of Ukraine in 2020, \%

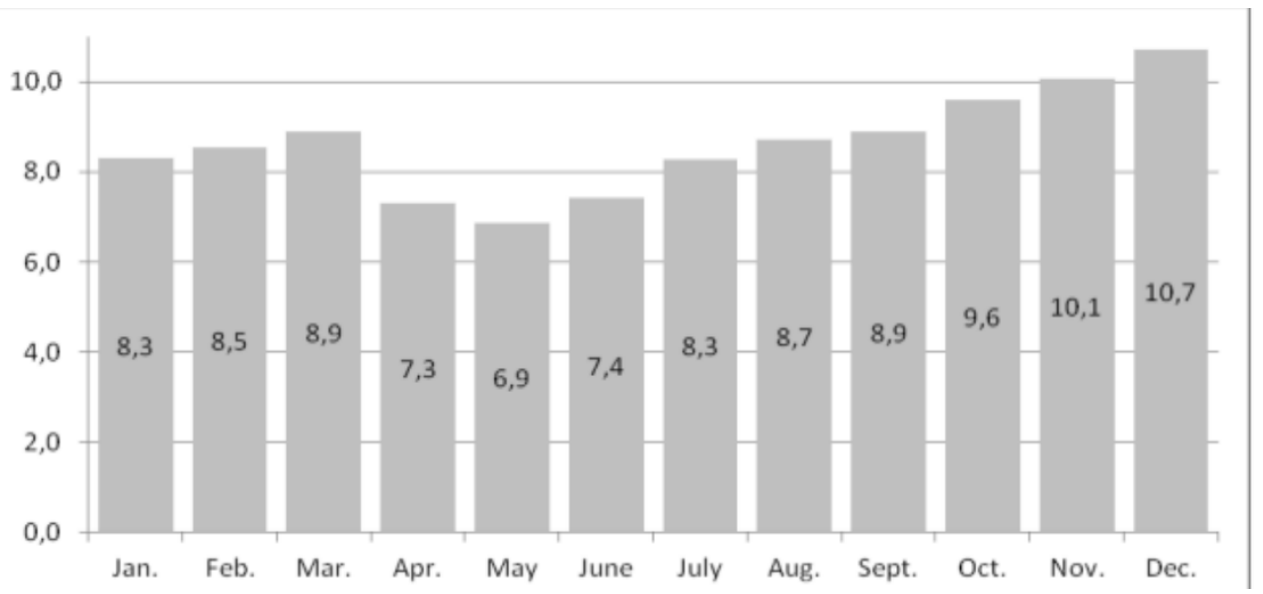

Figure 2. Foreign trade commodity turnover of Ukraine in 2020, bln USD

and energy products by 4.2 bln USD, as well as machinery, equipment, transport (by 2 bln USD).

It's necessary to mention that during this period, imports of food and agricultural products increased by 759 mln USD. These changes resulted in the growth of the share of food and agricultural products in the commodity structure of imports by 2.5 percentage points with the decrease in the share of fuel and energy products by 5.5 percentage points, while the share of other industries remained unchanged.

The leading role in the commodity structure of imports is played by machinery, equipment and transport (34.3\% of total imports), chemical products $(20 \%)$ and fuel and energy products $(14.7 \%)$. These three product groups account for almost $70 \%$ of total imports of goods to Ukraine.

In contrast to the physical volumes of exports, which remained almost unchanged, the physical volumes of imports of goods decreased by $11.8 \%$. The largest decrease in physical volumes took place in imports of hides, furs and fur products (by 24.4\%), but due to the relatively small share of goods in this group in total imports, this did not have a significant impact. Greater impact on the overall indicator had decrease in imports of machinery, equipment and transport (by 15.8\%) and chemical products (by $15.7 \%)$.
The physical volumes of imports of fuel and energy products also decreased by $15.1 \%$, while the value of imports of this commodity group decreased by $34.6 \%$. This reduction was caused by significantly lower prices for goods in this group. Thus, the price of natural gas imports for 2019 was 282 USD per ton, and for 2020 it was just 219 USD per ton. The cost of a ton of crude oil imports in 2019 was 513 USD, and for the same period in $2020-328$ USD.

In the geographical structure of Ukraine's commodity foreign trade in 2020, the leading partner of Ukraine was the EU (calculations include the UK). However, the EU countries' share decreased from $41.9 \%$ in 2019 to $41 \%$ in 2020. This change was due to the reduction in the value of trade by $8.4 \%$. As table 6 indicates, the EU is Ukraine's largest trading partner in both exports of goods (37.8\% of total exports) and imports (43.8\% of total imports).

Contrary to the general trend, the decline in exports to the EU countries was faster than in imports. According to the results of 2020 , exports to them decreased by $10.2 \%$, or 2.1 bln USD up to 18.6 bln USD, while imports fell by 1.8 bln USD or $6.9 \%$ to 21.3 bln USD. The reduction in exports to the EU was based on the decline in the supply of vehicles and spare parts to them by 1.4 bln USD (or $81.6 \%$ ) and industrial goods by $653 \mathrm{mln}$ USD (or 5.7\%). 
Table 6. Geographical structure of Ukraine's commodity exports and imports in $2020, \%$

\begin{tabular}{lll}
\hline & Export & Import \\
\hline EU & 37,8 & 43,8 \\
China & 14,4 & 15,3 \\
EAEU & 9,2 & 14,6 \\
Turkey & 5,0 & 4,4 \\
Other countries & 33,6 & 21,9 \\
\hline
\end{tabular}

At the same time exports of food products and beverages showed the increase of $76 \mathrm{mln}$ USD (or 1.8\%). It should be noted that in December 2020, compared to December 2019, exports of goods from Ukraine to the EU increased by a quarter.

Somewhat similar situation was observed in the dynamics of imports from the EU countries. The reduction of imports of fuels and lubricants by 1.4 bln USD or $42.7 \%$, vehicles by $542 \mathrm{mln}$ USD or by $15.5 \%$ and capital equipment (except for transport) by $326 \mathrm{mln}$ USD or $6.4 \%$ occurred with the parallel increase in imports of food and beverages by $354 \mathrm{mln}$ USD or $16.4 \%$.

The share of the Eurasian Economic Union (EAEU) countries in Ukraine's trade turnover also decreased from $14.9 \%$ in 2019 to $12 \%$ during 2020 . The rate of reduction in trade was higher than in trade with the EU and amounted to $24.5 \%$. This was largely due to the $28.7 \%$ reduction in trade with the Russian Federation. At the heart of this reduction is the decrease of 1.4 bln USD (or 35.3\%) in imports from Russia of fuels and lubricants. Despite this reduction, the goods of this group account for $56.7 \%$ of total imports from the Russian Federation. In general, imports from the EAEU countries decreased by $29.1 \%$.

The rate of decline in exports to the EAEU countries in the 2020 was lower than imports from them and amounted to $15 \%$ or $798 \mathrm{mln}$ USD. This was largely due to lower (by $576 \mathrm{mln}$ USD) volumes of industrial supplies.

If during 2020 Ukraine's trade with the EU countries, as well as with the EAEU countries, decreased, the dynamics of trade in goods with the other countries increased. The trade turnover with them increased by $875 \mathrm{mln}$ USD (or by $1.8 \%$ ) due to the growth in exports by 2.1 bln USD (or $8.6 \%$ ), while imports fell by 1.2 bln USD (or $5 \%$ ). It is important to stress that exports from Ukraine to China almost doubled (growth was $97.7 \%$ ), which contributed to the increase in the share of this country in the geographical structure of Ukraine's foreign trade to $14.9 \%$ (14.4\% in exports and $15.3 \%$ in imports). Higher export growth rates, while declining imports to countries other than the EU and the EAEU, contributed to the increase in the trade surplus. If in 2019 the positive trade balance with the countries, except EU and EAEU, was 0.2 bln USD, then in 2020 it was 3.5 bln USD.

The increase in the trade surplus with the countries other than the EU and the EAEU was due to the improving negative trade balance with China - from -5.6 bln USD to -1.2 bln USD - due to this fact the negative balance in trade with the Asian countries of 0.8 bln USD in 2019 was changed to the positive balance in 2020 in the amount of 3.1 bln USD, while maintaining positive trade balance with the African countries of 3,2 bln USD. Considering the negative trade balances with both unions - the EU with 5.1 bln USD and the EAEU with 3,4 bln USD - Ukraine's focusing on the improving the dynamics of increasing trade with the other countries can be viewed as positive factor that contributes to the partial compensation of the negative balance in trade with both the EU and the EAEU. It is also essential to develop the transport system for increasing the exports of agricultural and food products. So, COVID-19 has become a new challenge for the structure of Ukraine's foreign trade, and the national economy's prospects will depend largely on the level of the international technological competitiveness of the country $[32,33]$.

\section{Conclusions}

Europe was $53.6 \%$ of total merchandise exports of Ukraine. The European countries are the main consumers of the Ukrainian products.

Europe and Asia consumed $86.97 \%$ of Ukrainian goods in 2019, Africa $-9.97 \%$. The role of the Asian countries as suppliers of goods for Ukraine is becoming more important. Ukraine has been having the negative balance of trade in goods with Europe since $2005(-1785 \mathrm{mln}$ USD), which has grown to - 11262.4 mln USD in 2019 , while the trade balance of Ukraine with Asia had been positive throughout the analyzed period up until 2019 (-748.4 mln USD). The trade balance of goods of Ukraine with the African countries is positive, and with those of America - negative. The share of imports from the American countries in 2019 was $7.24 \%$ of total imports of goods of Ukraine.

The analysis of the Ukrainian exports and imports of the selected industrial goods - "XVI. Machines, equipment and mechanisms, electric and technical equipment" and "XVII. Ground, air and water transport facilities" demonstrates that in exports of Ukraine the share of those groups of goods in all the exports of goods is decreasing (in $2016-11.53 \%$, in $2019-10.68 \%$ ) while the share of those groups of goods in all the imports of goods is increasing (in $2016-27.64 \%$, in $2019-32.04 \%$ ).

The reduction in the value of world trade in the 2020 due to the COVID-19 pandemic was not as significant as after the global crisis of 2008-2009. During 2020 the WTO improved its forecast for the dynamics of world trade in 2020. The decrease in Ukraine's foreign trade in 2020 by $6.4 \%$ is fully consistent with the projected WTO reduction of world trade in 2020 by $9.2 \%$. During the last two months of 2020 , for the first time since the beginning of COVID-19, the growth in the value of trade turnover of Ukraine was recorded compared to the same months of the previous year, which indicates a gradual resumption of foreign trade in the context of easing quarantine restrictions. The reduction in the value of foreign trade in 2020 by $6.4 \%$ with the fall in their physical volume by $4.7 \%$ indicates the prevailing trend of the decline in the prices. The world oil prices fell which resulted in the decrease of $34.6 \%$ in the cost of imports of fuel and energy prod- 
ucts, while reducing purchases of their physical volumes by $15.1 \%$.

The prices for agricultural and food products increased, which resulted in the growth in the value of trade in these goods by $2.9 \%$ while reducing their physical volume by $8.3 \%$. So, one of the prospects is the development of the country's transport system for exporting agricultural and food products. Despite the general trend of declining trade, exports from Ukraine to China have doubled, leading to the increase in China's role in Ukraine's economy. The reduction of trade with the countries of the EU and the EAEU is observed against the background of the increased trade with the other countries, which, provided that the trade surplus is maintained, contributes to improving Ukraine's balance of payments.

Finally, COVID-19 demonstrated that agricultural and food products are of primary importance during the challenging times. In 2020 Ukraine improved trade with the Asian countries, especially China; however, the rise of the prices for the agricultural and food products makes it logical for the future of Ukraine to pay more attention to the development of the transport system in order to increase their exports to the developed countries of the West and to the prospective economies of the East and the South.

\section{References}

[1] A. Bielinskyi, I. Khvostina, A. Mamanazarov, A. Matviychuk, S. Semerikov, O. Serdyuk, V. Solovieva, V. Soloviev, IOP Conference Series: Earth and Environmental Science 628, 012019 (2021)

[2] S. Semerikov, H. Kucherova, V. Los, D. Ocheretin, CEUR Workshop Proceedings 2845, 22 (2021)

[3] J. Baylis, S. Smith, P. Owens, The globalization of world politics. An introduction to International relations, 8th edn. (Oxford University Press, 2020)

[4] V. Jeníček, V. Krepl, Agricultural Economics (Zemědělská Ekonomika) 55, 211 (2009)

[5] S. Sen, Economics Working Paper Archive 635, Levy Economics Institute (2010)

[6] S.K. Gnangnon, The Journal of International Trade \& Economic Development 29, 211 (2020)

[7] A.U. Santos-Paulino, The Journal of International Trade \& Economic Development 26, 693 (2017)

[8] W. Leontief, A. Strout, Multiregional input-output analysis, in Structural interdependence and economic development, edited by T. Barna (Palgrave Macmillan, 1961), pp. 119-150, ISBN 978-1-34981634-7

[9] L. von Bertalanffy, General System Theory. Foundations, Development, Applications (Braziller, New York, 1969), ISBN 0807604534

[10] G.J. Klir, An Approach to General Systems Theory (Van Nostrand Reinhold Co, 1969)

[11] L. Friendshuh, L. Troncale, Identifying Fundamental Systems Processes for a General Theory of Systems (GTS), in Proceedings of the $56^{\text {th }}$ Annual conference,
International Society for the Systems Sciences (ISSS) (2012), p. 23

[12] V. Soloviev, A. Belinskiy, Communications in Computer and Information Science 1007, 276 (2019)

[13] V. Soloviev, A. Bielinskyi, V. Solovieva, CEUR Workshop Proceedings 2393, 434 (2019)

[14] V. Soloviev, N. Moiseienko, O. Tarasova, CEUR Workshop Proceedings 2393, 905 (2019)

[15] V. Soloviev, N. Moiseienko, O. Tarasova, Communications in Computer and Information Science 1175 CCIS, 231 (2020)

[16] V. Soloviev, A. Bielinskyi, O. Serdyuk, V. Solovieva, S. Semerikov, CEUR Workshop Proceedings 2732, 455 (2020)

[17] V. Soloviev, V. Solovieva, A. Tuliakova, A. Hostryk, L. Pichl, CEUR Workshop Proceedings 2713, 53 (2020)

[18] V. Soloviev, O. Serdiuk, S. Semerikov, A. Kiv, CEUR Workshop Proceedings 2713, 21 (2020)

[19] A. Bielinskyi, S. Semerikov, O. Serdyuk, V. Solovieva, V. Soloviev, L. Pichl, CEUR Workshop Proceedings 2713, 372 (2020)

[20] V. Derbentsev, S. Semerikov, O. Serdyuk, V. Solovieva, V. Soloviev, E3S Web of Conferences 166, 13031 (2020)

[21] S. Semerikov, S. Chukharev, S. Sakhno, A. Striuk, V. Osadchyi, V. Solovieva, T. Vakaliuk, P. Nechypurenko, O. Bondarenko, H. Danylchuk, E3S Web of Conferences 166, 00001 (2020)

[22] N. Datskevych, Netherlands 'will pay the price' for blocking Turkish visit - Erdoğan (2020), https: // tinyurl.com/z74dz8xt

[23] S. Sardak, S. Radziyevska, I. Us, CEUR Workshop Proceedings 2422, 84 (2019)

[24] The State Statistics Service of Ukraine database (2020), http://www.ukrstat.gov.ua

[25] V. Halasiuk, Ukraine on the eve of the fourth industrial revolution (2016)

[26] G. Gereffi, Review of International Political Economy 21, 9 (2014)

[27] World Development Report 2020: trading for development in the age of global value chains (World Bank Group, Washington, D.C., 2020), https:// tinyurl.com/252wpfby

[28] World merchandise trade fell $14 \%$ in volume, $21 \%$ in value in $q 2$ amid global lockdown (2020), https://www.wto.org/english/news_ e/news20_e/stat_23sep20_e.htm

[29] Trade shows signs of rebound from covid-19, recovery still uncertain (2020), https: //www . wto.org/ english/news_e/pres20_e/pr862_e.htm

[30] A.J. Morrison, D.A. Ricks, K. Roth, Organizational Dynamics 19, 17 (1991)

[31] The State Customs Service of Ukraine database (2021), https://customs.gov.ua/

[32] D. Pokryshka, European Science 3, 32 (2019)

[33] N. Cherkas, Ph.D. thesis, Kyiv, Ukraine (2018) 